\title{
Opportunistic cervical cancer screening by papanicolaou stain Pap smear among women: a pilot study at urban health training centre of All India Institute of Medical Sciences, Patna, Bihar, India
}

\author{
Ruchi Sinha ${ }^{1}$, Pragya Kumar ${ }^{2}$, Geetika Singh ${ }^{2 *}$, Rubina Saha ${ }^{2}$
}

\author{
${ }^{1}$ Department of Pathology and Lab Medicine, AIIMS, Patna, Bihar, India \\ ${ }^{2}$ Department of Community and Family Medicine, AIIMS, Patna, Bihar India
}

Received: 18 May 2020

Accepted: 25 May 2020

\author{
*Correspondence: \\ Dr. Geetika Singh, \\ E-mail: singgeet@gmail.com
}

Copyright: () the author(s), publisher and licensee Medip Academy. This is an open-access article distributed under the terms of the Creative Commons Attribution Non-Commercial License, which permits unrestricted non-commercial use, distribution, and reproduction in any medium, provided the original work is properly cited.

\begin{abstract}
Background: Cancer of the uterine cervix is the second most common cancer among women world-wide and accounts for 17\% of all cancer deaths among females aged 30-69 years in India. Locally advanced cervical cancer is rampant in Bihar because of the high prevalence of associated risk factors. However, there is lack of organized screening programmes and treatment facilities for these patients. Thus, the study aimed at screening women for cervical cancer opportunistically during their visit to the health centres and to assess the various socio-demographic and other risk factors associated with positive screening test results.

Methods: Using purposive sampling technique, all women aged 18-59 years who visited the centre for any purpose were interviewed using a pre-designed questionnaire. All eligible women were screened using the conventional Pap Smear and evaluation was done using the 2014 Bethesda system. This study is still underway and 71 women have been screened so far. An interim analysis was done.

Results: Only $4.23 \%$ of the women ever had Pap smear testing in their life earlier. Mean age was $35.3 \pm 9.12$ years and majority of the women were married and multi-parous. Vaginal discharge $(55.74 \%)$ was the most common perceived gynecological morbidity. Most (36.62\%) smears were reported as inflammatory cervical smears while epithelial cell abnormalities were seen in $4(5.63 \%)$ cases.

Conclusions: This study reiterates the need to start organized cervical screening program not only at tertiary center but also at primary health centers which will definitely help to reduce the burden to some extent
\end{abstract}

Keywords: Cervical cancer, Opportunistic screening, Pap smear

\section{INTRODUCTION}

Cancer of the uterine cervix is the second most common cancer among women world-wide. ${ }^{1}$ It is the one of the leading causes of cancer mortality, accounting for $17 \%$ of all cancer deaths among women aged between 30 and 69 years in India. It is estimated that cervical cancer will occur in approximately 1 in 53 Indian women during their lifetime compared with 1 in 100 women in more developed regions of the world. ${ }^{2}$ Further it has been revealed that one out of every five women in the world suffering from this disease belongs to India. More than three-fourths of these patients are diagnosed at advanced stages leading to poor prospects of long-term survival and cure. $^{3}$ India also has the highest age standardized incidence of cervical cancer in South Asia at 22, compared to 19.2 in Bangladesh, 13 in Sri Lanka, and 2.8 in Iran. ${ }^{4}$

Coming to the state of Bihar, the patient registry at Mahavir Cancer Sansthan, Patna showed that among the annual registered new patients from all cancers, cervical 
cancer constituted $14 \%$ and $99 \%$ of these patients reported at stage $2 \mathrm{~b}$ and beyond. ${ }^{5}$ Another study of the same region also found a high prevalence (52\%) of cervical cancer among all gynecological malignancies. ${ }^{6}$ Locally advanced cervical cancer is thus commonly seen in Bihar because of the high prevalence of associated risk factors like low socioeconomic status, poor access to health care, high parity, early age of marriage and first pregnancy, smoking, persistence of genital infection specially HPV, low immune status, poor genital hygiene and nutritional status. Besides, there is lack of organized screening programmes and treatment facilities for these patients in this state. ${ }^{7}$

Unlike most other cancers, cervical cancer is readily preventable when effective programs are conducted to detect and treat its precursor lesions. The easy accessibility of the cervix and the propensity of the cancer cells to exfoliate from its surface have enabled us to study the process of malignant transformation in the cervix in very early stage. ${ }^{8}$ Many studies have shown that carcinoma in situ can be detected for several years before it progresses to invasive cancer by cytological screening. ${ }^{9}$ The screening programs in several countries have been able to reduce the incidence and mortality from cervical cancer by $60 \%$ as observed by Hakama et al. ${ }^{10}$

As per the WHO guidelines for Cervical Cancer Prevention 2013, the recommended screening methods are any of the following three tests: human papillomavirus (cut-off level $\geq 1.0 \mathrm{pg} / \mathrm{ml}$ ), cytology (cutoff level ASC-US+) and visual inspection with acetic acid (VIA). ${ }^{11}$ Pap smear test is highly sensitive, specific method and currently the most widely used approach for detecting precancerous lesions and thereby a helpful tool in cervical cancer. The Pap smear is a simple test to collect a small sample of exfoliated cells from the cervix which helps to diagnose precancerous and cancerous conditions of the cervix. It also aids in diagnosing infections and inflammation of the lower reproductive tract which if left untreated may progress to premalignant lesions. ${ }^{12}$ Cytological screening has been found to reduce the incidence of cervical cancer by $80 \% .{ }^{13}$ It is estimated that only about $5 \%$ of women in developing world have been screened for the disease with pap smear, compared to $40-50 \%$ in developed countries. ${ }^{14}$ The main reasons for this are lack of awareness, low educational levels, low socio-economic state, multiparity, home deliveries and prolonged labor. ${ }^{12}$ Asymptomatic women are usually not screened for cervical cancer even once in their lifetime in India. ${ }^{15}$ The implementation of opportunistic screening programmes becomes very important in such circumstances to minimize cervical cancer disease. ${ }^{16}$ At present, opportunistic screening in India is practiced only at tertiary care centres where Pap smear is offered to women with symptoms related to reproductive tract infections.

So, unfortunately, till date there are no suitable, large scale, cost effective; population-based screening programs in India to detect prevalence of HPV infection and preinvasive stages of carcinoma cervix. Hence, it becomes imperative to introduce hospital or institutionbased screening programs which may not be as effective as nationally organised screening programmes but will definitely help to decrease the load considerably. ${ }^{17}$ Thus this study aims at screening women for cervical cancer opportunistically during their visit to the health centres and explore the various socio-demographic and other risk factors associated with this deadly condition.

\section{METHODS}

A community based cross-sectional pilot study conducted at Khagaul, the Urban Health Training Centre (UHTC) of department of community and family medicine, AIIMS, Patna. The study population constituted all women aged 18-59 years who attended UTHC for any purpose during last 3 months (December 2019 to February 2020).

\section{Inclusion criteria}

- Included all women between 18-59 years of age who gave consent for the study.

\section{Exclusion criteria}

- Women who were not willing to participate in the study

- Known cases of cancer cervix

- Treated cases of cervical cancer

- Post-hysterectomy cases.

Purposive sampling technique was used. All eligible women who visited the health centre for any reason were interviewed using a pre-tested questionnaire regarding socio-demographic details, fertility profile and other relevant history. All women were screened with conventional Pap smear.

\section{Pap smear examination}

Per-speculum cervical examination was initially done to assess the smoothness of cervix, presence of any discharge or foul smell, any abnormal growth or bleeding at the time of taking the smear. Cervical smears were then taken from the eligible women with the help of disposable Ayer's spatula and cyto brush to collect specimen from the squamocolumnar junction. The cellular material obtained on the spatula/ cyto brush was quickly smeared on a clean glass slide. Two smears were prepared for each case. The glass slides were then fixed immediately by immersing them into the coplin jar containing $95 \%$ methanol and later sent to the pathological department at AIIMS, Patna for microscopic examination.

Evaluation was done using 2014 Bethesda system for reporting cervical cytology. ${ }^{18}$ The Pap smear reports were distributed to the women on subsequent visit. Those cases 
having abnormal cytology as well as those having persistent complaints like vaginal discharge or abnormal uterine bleeding were referred to the gynecology department of AIIMS, Patna for appropriate treatment and follow-up.

\section{Statistical analysis}

The collected data was compiled, tabulated and analyzed using statistical software SPSS, version-22. Descriptive statistics were computed with percentages, mean and standard deviation (SD) and valid inferences were then drawn.

\section{RESULTS}

In this pilot study, total 80 eligible women had visited the health centre, out of which most i.e. 71 (88.75\%) women were opportunistically screened while remaining 9 $(11.25 \%)$ refused to undergo Pap smear testing. It is also important to highlight that only $4.23 \%$ (3 out of 71 ) women had Pap smear testing in their life earlier.

Table 1: Sociodemographic profile of females attending UHTC $(\mathrm{N}=71)$.

\begin{tabular}{|c|c|c|c|}
\hline \multicolumn{2}{|l|}{ Variable } & \multirow{2}{*}{$\begin{array}{l}\text { Number } \\
1\end{array}$} & \multirow{2}{*}{$\begin{array}{l}\text { Percentage }\left(\mathbf{C I}^{\mathrm{a}}\right) \\
1.40(0.04-7.6)\end{array}$} \\
\hline \multirow{5}{*}{$\begin{array}{l}\text { Age } \\
\text { (years) }\end{array}$} & $<19$ & & \\
\hline & $20-29$ & 21 & $29.58(19.3-41.6)$ \\
\hline & $30-39$ & 24 & $33.80(23.0-46.0)$ \\
\hline & $40-49$ & 17 & $23.94(14.6-35.5)$ \\
\hline & $50-59$ & 8 & $11.27(4.99-21.0)$ \\
\hline \multirow{2}{*}{ Religion } & Hindu & 69 & $97.18(90.2-99.7)$ \\
\hline & Muslim & 2 & $2.82(0.3-9.8)$ \\
\hline \multirow{4}{*}{ Caste } & General & 18 & $25.35(15.8-37.0)$ \\
\hline & OBC & 41 & $57.75(45.4-69.4)$ \\
\hline & $\mathrm{SC}$ & 11 & $15.49(8.0-26.0)$ \\
\hline & ST & 1 & $1.41(0.04-7.6)$ \\
\hline \multicolumn{4}{|l|}{ Education } \\
\hline \multicolumn{2}{|l|}{ Illiterate } & 26 & $36.62(25.5-48.9)$ \\
\hline \multicolumn{2}{|c|}{ Up to middle } & 31 & $43.66(31.9-55.9)$ \\
\hline \multicolumn{2}{|c|}{ Up to Intermediate } & 9 & $12.68(5.96-22.7)$ \\
\hline \multicolumn{2}{|c|}{ Graduate and above } & 5 & $7.04(2.33-15.7)$ \\
\hline \multicolumn{4}{|c|}{ Occupation } \\
\hline \multicolumn{2}{|c|}{ Unemployed } & 52 & $73.24(61.4-83.1)$ \\
\hline \multicolumn{2}{|c|}{ Unskilled worker } & 10 & $14.08(6.9-24.4)$ \\
\hline \multicolumn{2}{|c|}{ Skilled worker } & 7 & $9.86(4.1-19.3)$ \\
\hline \multicolumn{2}{|c|}{ Service } & 1 & $1.41(0.04-7.6)$ \\
\hline \multicolumn{2}{|c|}{ Self-employed } & 1 & $1.41(0.04-7.6)$ \\
\hline \multirow{5}{*}{$\begin{array}{l}\text { Socio- } \\
\text { economic } \\
\text { status }\end{array}$} & I & 3 & $4.23(0.88-11.9)$ \\
\hline & II & 10 & $14.08(6.97-24.4)$ \\
\hline & III & 19 & $26.76(16.9-38.6)$ \\
\hline & IV & 26 & $36.62(25.5-48.9)$ \\
\hline & $\mathrm{V}$ & 13 & $18.30(10.1-29.3)$ \\
\hline \multirow{2}{*}{$\begin{array}{l}\text { Any } \\
\text { addictions }\end{array}$} & Yes & 14 & $19.72(11.2-30.1)$ \\
\hline & No & 57 & $80.28(69.1-88.8)$ \\
\hline
\end{tabular}

a-Confidence interval
Table 2: Marital and obstetric profile of females attending UHTC (N=71).

\begin{tabular}{|c|c|c|}
\hline Variable & Number & Percentage (CI) \\
\hline \multicolumn{3}{|l|}{ Marital status } \\
\hline Married & 68 & $95.77(88.1-99.1)$ \\
\hline Widowed & 2 & $2.82(0.34-9.8)$ \\
\hline Separated/ divorced & 1 & $1.41(0.04-7.6)$ \\
\hline \multicolumn{3}{|c|}{ Age at marriage (years) } \\
\hline $11-15$ & 19 & $26.76(16.9-38.6)$ \\
\hline $16-20$ & 40 & $56.3(44.1-68.1)$ \\
\hline $21-25$ & 11 & $15.49(8.00-26.03)$ \\
\hline $26-30$ & 1 & $1.41(0.04-7.6)$ \\
\hline \multicolumn{3}{|l|}{ Parity } \\
\hline Nulliparous & 1 & $1.41(0.04-7.6)$ \\
\hline Primipara & 8 & $11.27(5.0-21.0)$ \\
\hline Multipara & 62 & $87.32(77.3-94.0)$ \\
\hline \multicolumn{3}{|c|}{ Age at first childbirth (years) } \\
\hline $11-15$ & 5 & $7.14(2.4-15.9)$ \\
\hline $16-20$ & 38 & $54.29(41.9-66.3)$ \\
\hline $21-25$ & 23 & $32.86(22.1-45.1)$ \\
\hline $26-30$ & 4 & $5.71(1.6-14.0)$ \\
\hline \multicolumn{3}{|l|}{ Contraceptive usage } \\
\hline None & 28 & $39.44(28.0-51.8)$ \\
\hline Barrier & 5 & $7.04(2.33-15.7)$ \\
\hline IUCD & 5 & $7.04(2.33-15.7)$ \\
\hline $\mathrm{OCP}$ & 4 & $5.63(1.56-13.8)$ \\
\hline Tubal ligation & 28 & $39.44(28.0-51.8)$ \\
\hline Others & 1 & $1.41(0.04-7.6)$ \\
\hline
\end{tabular}

The sociodemographic characteristics of the females are shown in Table 1. Majority $(87.32 \%)$ of the women included in the study were in the age group of 20-49 years with mean age of $35.3 \pm 9.12$ years, $97.18 \%$ were Hindus and more than half $(57.75 \%)$ belonged to Other Backward Class. Of 71 women, 31 women $(43.66 \%)$ had studied till middle class while $26(36.62 \%)$ were illiterate. Three-fourths (73.24\%) were unemployed. Most of the women were of lower socio-economic status according to modified B. G. Prasad social classification. Around 20\% women gave history of addictions like smoking / tobacco use and occasional drinking. Regarding the marital and obstetric profile of females attending UHTC, out of 71 women, majority $(95.77 \%)$ were married and were in monogamous relationship. The mean age at marriage was $17.89 \pm 3.48$ years while mean age at first childbirth was $20.04 \pm 3.16$ years. Most i.e., $62(87.32 \%)$ women were multiparous (Woman having borne more than one child). Of 71 women, $43(60.56 \%)$ women were using some kind of family planning methods with majority 28 (39.44\%) of women had undergone tubal ligation (Table 2).

Table 3 reveals the presenting complaints as perceived by the study population. Only $21(29.58 \%)$ women did not suffer from any morbidity. Among those having complaints, vaginal discharge was the most common symptom found in $55.74 \%$, abnormal uterine bleeding in 
$18.03 \%$ followed by urinary tract problems in $6.56 \%$ and lower abdominal pain in $4.92 \%$ of women.

Table 3: Type of perceived reproductive tract morbidity.

\begin{tabular}{|lll|}
\hline Symptoms & Number & Percentage \\
\hline None & 21 & $29.58 \%$ \\
\hline Any morbidity & 50 & $70.42 \%$ \\
\hline Discharge per vaginum & 34 & $55.74 \%$ \\
\hline Abnormal uterine bleeding & 11 & $18.03 \%$ \\
\hline Dysuria/burning micturition & 4 & $6.56 \%$ \\
\hline Lower pain abdomen & 3 & $4.92 \%$ \\
\hline Backache & 2 & $3.28 \%$ \\
\hline Pruritis vulvae & 2 & $3.28 \%$ \\
\hline Post-coital bleeding & 2 & $3.28 \%$ \\
\hline Dyspareunia & 1 & $1.64 \%$ \\
\hline Post-menopausal bleeding & 1 & $1.64 \%$ \\
\hline Others & 1 & $1.64 \%$ \\
\hline Total complaints & 61 & $100.0 \%$ \\
\hline *- Some women had more than one complaint.
\end{tabular}

Table 4: Pap smear cytology of study population $(\mathrm{N}=71)$.

\begin{tabular}{|c|c|c|c|}
\hline & Pap smear findings & Number & Percentage \\
\hline & Unsatisfactory & 2 & $2.82 \%$ \\
\hline I & \multicolumn{3}{|c|}{$\begin{array}{l}\text { Negative for intraepithelial lesion or malignancy } \\
\text { (NILM) }\end{array}$} \\
\hline 1. & \multicolumn{3}{|l|}{ Non-neoplastic changes } \\
\hline a. & Normal cervical smear & 30 & $42.25 \%$ \\
\hline b. & $\begin{array}{l}\text { Inflammatory cervical } \\
\text { smear }\end{array}$ & 26 & $36.62 \%$ \\
\hline c. & Atrophic changes & 2 & $2.82 \%$ \\
\hline 2. & Organisms & & \\
\hline a. & Bacterial vaginosis & 5 & $7.04 \%$ \\
\hline b. & Candidiasis & 2 & $2.82 \%$ \\
\hline II & \multicolumn{3}{|c|}{ Epithelial cell abnormalities } \\
\hline 3. & \multicolumn{3}{|l|}{ Squamous cell } \\
\hline a. & ASCUS $^{*}$ & 2 & $2.82 \%$ \\
\hline b. & ASC-H & 1 & $1.41 \%$ \\
\hline c. & LSIL & 0 & $0 \%$ \\
\hline d. & HSIL & 1 & $1.41 \%$ \\
\hline e. & $\mathrm{SCC}$ & 0 & $0 \%$ \\
\hline 4. & $\begin{array}{l}\text { Glandular cell } \\
\text { abnormality }\end{array}$ & 0 & $0 \%$ \\
\hline
\end{tabular}

*-Atypical squamous cells of undetermined significance (ASCUS), low-grade squamous intraepithelial lesion (LSIL), highgrade squamous intraepithelial lesion (HSIL), squamous cell carcinoma (SCC).

Of the total 71 Pap smears collected, 2(2.82\%) were found to be unsatisfactory for evaluation on screening. Majority $30(42.25 \%)$ were Normal smears followed by Inflammatory smears in $26(36.62 \%)$. Atrophic changes were observed in 2 (2.82\%). Organisms like bacterial vaginosis $(7.04 \%)$ and candida species $(2.82 \%)$ were also reported. Epithelial cell abnormalities were seen in 4
(5.63\%) cases, out of which $2.82 \%$ had ASCUS, ASC-H was found only in $1.41 \%$ and HSIL was reported in $1.41 \%$ women. However, there was no case of LSIL or SCC or any glandular cell abnormality (Table 4).

On per-speculum examination of the cervix, more than half i.e., $39(54.93 \%)$ of women had normal looking cervix, $26(36.62 \%)$ discharge, $9(12.68 \%)$ bled on touch, $3(4.23 \%)$ abnormal growth and cervical erosion was found in $2(2.82 \%)$ while prolapse was seen in $1(1.41 \%)$ of women (Figure 1).

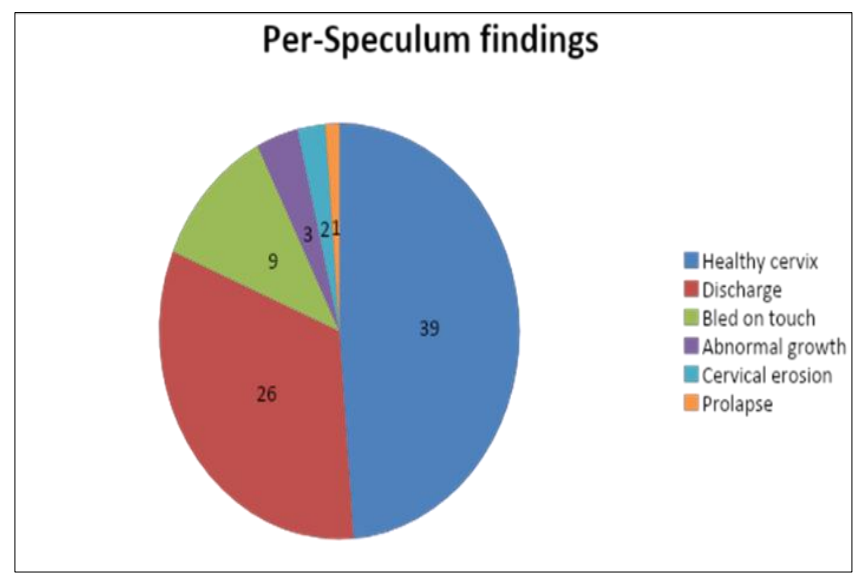

Figure 1: Per-speculum findings among study population $(\mathrm{N}=71)$.

\section{DISCUSSION}

Although cervical cancer is on a declining trend in India, still it continues to be a major public health problem for women in India. In this pilot study, most of the women $(95.77 \%)$ had Pap test for the first time in their lives which is similar to another study where only $5 \%$ of the women had a previous Pap smear test. ${ }^{19}$ In spite of repeated efforts, there were also a few refusals $(11.25 \%)$ as these women believed that pap smear test was not required since they were asymptomatic while others felt it to be embarrassing.

The socio-demographic findings of the present study correspond with the results obtained from another study conducted in similar settings. ${ }^{20}$ The analyzed age group in the current study ranged from 18 to 59 years, out of which maximum women were from the age group of 3039 years with mean age of $35.3 \pm 9.12$ years. This is similar to the findings of another study where majority of women belonged to 31-40 years age group with mean age of $38.6 \pm 6.29$ years. $^{20}$ This age group is appropriate for screening considering the fact that the common age to develop cervical cancer is 40-50 years and its precursor lesion usually occurs 5-10 years earlier. ${ }^{21}$ It is therefore recommended that every woman should undergo pap test at least once in her life before the age of 45 years. ${ }^{21,22}$

According to this study, around 32 (45.07\%) women were married before the legal age of marriage which is 
comparable to NFHS-4 data of Bihar where $42.5 \%$ women were married before 18 years of age. ${ }^{23}$ Similarly, the mean age of childbirth $(20.04 \pm 3.16$ years $)$ was also found to be quite early. Early age of marriage predisposes to early sexual contact and childbearing which contributes to cervix cancer. Further, majority $(87.32 \%)$ of women in this study were multiparous.

Multiparity has been found to be associated with cervical cancer in several studies. ${ }^{24,25}$

Table 5: Comparison of epithelial cell abnormalities across various studies.

\begin{tabular}{|c|c|c|c|c|c|}
\hline Studies & ASCUS & ASC-H & LSIL & HSIL & SCC \\
\hline Present study & $2.82 \%$ & $1.41 \%$ & - & $1.41 \%$ & - \\
\hline Verma $A$ et $\mathrm{al}^{20}$ & $1 \%$ & - & $5.5 \%$ & $2.5 \%$ & - \\
\hline Mishra $\mathrm{P}$ et $\mathrm{al}^{26}$ & $3.5 \%$ & $0.5 \%$ & $4 \%$ & $1 \%$ & $0.5 \%$ \\
\hline Omna $S$ et al ${ }^{27}$ & $4 \%$ & - & $6.8 \%$ & $6 \%$ & $2.3 \%$ \\
\hline Sachan et $\mathrm{al}^{28}$ & $2.9 \%$ & - & $5.09 \%$ & $0.48 \%$ & - \\
\hline Padmini et $\mathrm{al}^{29}$ & $8 \%$ & - & $5 \%$ & $3 \%$ & $1 \%$ \\
\hline
\end{tabular}

Regarding contraception, around $40 \%$ women did not use any kind of family planning methods. This is higher than in the studies by Verma et al and Mishra et al, where $38 \%$ and $31.5 \%$ of women did not use any family planning methods respectively. ${ }^{20,26}$ The reason for this low usage of contraception could be lack of awareness regarding contraceptive techniques due to low literacy levels among study population. The percentage of women using IUCD (7\%) and OCP's (4\%) were observed to be similar in both the studies, however, number of tubal ligations $(39.44 \%)$ in the present study were double than that of the comparative study $(18 \%){ }^{26}$

Vaginal discharge $(55.74 \%)$ was the most frequently perceived gynecological morbidity which is found congruent to other studies where $52 \%$ and $41.5 \%$ women complained of discharge per vaginum respectively. ${ }^{26,27}$ Even fungal infections like candidasis were observed in $2.82 \%$ cases on cytology which is similar to a study in Karnataka $(0.39 \%) .{ }^{17}$ This can be attributed to very poor genital hygiene which could be due to substandard living conditions as well as lack of water and other resources for proper sanitation. Per-speculum examination findings were also in concordance with other studies where healthy-looking cervix was observed in 50.5\% and 53\% women followed by discharge in $57.5 \%$ and $48 \%$ of cases respectively. ${ }^{20,26}$

In the present study, more than half of women $(54.93 \%)$ women had abnormal cytology with maximum being inflammatory smears $(36.62 \%)$. Other studies like Kulkarni et al, observed a higher rate of $73.7 \%$ while Sachan et al, reported $42.66 \%$ as inflammatory smears. ${ }^{17,28}$ High percentage of inflammatory pattern also indicates poor perineal hygiene. Such women with persistent inflammation should be appropriately treated; otherwise, the chance of development of cervical intraepithelial lesions increases. A repeat Pap smear should be taken following appropriate treatment.
Epithelial cell abnormalities were observed in 4 (5.63\%) cases, out of which $2(2.82 \%)$ were ASCUS while ASC$\mathrm{H}$ and HSIL cases were reported in 1 (1.41\%) each. Comparison of epithelial cell abnormality in this study with other studies in the literature is shown in Table 5.

According to various studies conducted in India, the overall prevalence of cytological abnormality is high. The differences in the prevalence of inflammatory changes and cervical dysplasia could have been the result of social and cultural differences, age, sexual activity level, incidence of related infections, and presence or absence of cervical screening programs in different locality and societies. Although only 4 (5.63\%) women were found to have epithelial abnormalities on cytology in the present study, the major limitation of the study is that it was a pilot study with small sample size, so the final results may vary. However, this study is first of its kind in Bihar and there is an imperative need to introduce more such hospital or institution-based screening tools to bring out the real scenario of cervical cancer in this state.

\section{CONCLUSION}

Cervical cancer is still a major cause of morbidity and mortality among female population. Poverty, illiteracy, ignorance, early age of marriage, early age at first pregnancy, multiparity, lack of screening and treatment facilities are the major contributing factors. Cervical smear cytology assists in the early detection of precancerous lesions of the cervix thereby downstaging cervical neoplasias and also helps in the diagnosis of specific infections of the female genital tract.

In India, with lack of centrally organised populationbased screening program for cervical cancer, such opportunistic screening with little extra effort to cover a greater number of women at risk by counselling and encouraging them to involve in screening program 
regularly will definitely help to reduce the country's burden of cervical cancer. Furthermore, all women who come for screening should be educated regarding the benefits and implications of Pap smear examination. Information, education and strategic communication methods targeting such eligible women should be strengthened to further promote this cause.

\section{ACKNOWLEDGMENTS}

Authors would like to thank all the women who participated in the study.

Funding: No funding sources

Conflict of interest: None declared

Ethical approval: The study was approved by the Institutional Ethics Committee

\section{REFERENCES}

1. World Health Organization. WHO guidance note: comprehensive cervical cancer prevention and control: a healthier future for girls and women, 2013. Available at: https://www.who.int/reproductive health/publications/cancers/9789241505147/en/. Accessed $2^{\text {nd }}$ May 2020.

2. Bobdey S, Sathwara J, Jain A, Balasubramaniam G. Burden of cervical cancer and role of screening in India. Indian J Med Paediatr Oncol. 2016;37:278-85.

3. Government of India-WHO Collaborative Programme: Guidelines for Cervical Cancer Screening Programme, 2005. Available at: http://screening.iarc.fr/doc/WHO_India_CCSP_guid elines_2005.pdf. Accessed $1^{\text {st }}$ May 2020.

4. Aswathy S, Javed R, Avani D. Epidemiology of cervical cancer with special focus on India. Int $\mathrm{J}$ Women Health. 2015;7:405-14.

5. Gahlot V, Kumar R. Epidemiology of cervical cancer in state of Bihar India: Hospital based study. Br J Med Health Res. 2016:3(9):7-14.

6. Kumari A, Pankaj S, Choudhary V, Kumari A, Nazneen S, Kumari J. Retrospective analysis of patients of cervical cancer a tertiary center in Bihar. Indian J Cancer. 2018;55:70-3.

7. Trivedi V, Chauhan R, Rani R, Singh U, Ghosh M. Cervical cancer in Bihar: an exploration of opportunities and challenges. Int $\mathbf{J}$ Current Res. 2017;9(5):50614-8.

8. Anderson GH, Boyes DA, Benedet JL, Le Riche JC, Matisic JP, Suen KC, et al. Organization and results of the cervical cytology screening programme in British Columbia. Brit Med J. 1988;296:975-8.

9. World Health Organization. Cervical Cancer Screening Programme: Managerial Guidelines, 1992. Available at: https://apps.who.int/iris/handle/ 10665/39478. Accessed 30 ${ }^{\text {th }}$ April 2020.

10. IARC. Working Group on Cervical cancer screening, 1987. Summary Chapter. In: Hakama M, Miller AB, Day NE, Eds. Screening for Cancer of the Uterine Cervix. Lyon, International Agency for Research on cancer: No.76 IARC Scientific publications; 1987:133-44.

11. WHO guidelines: Screening and treatment of precancerous lesions for cervical cancer prevention, 2013. Available at: http://apps.who.int/iris/bitstream/ 10665/94830/1/9789241548694_eng.pdf. Accessed on $29^{\text {th }}$ April 2020.

12. Ratnam KP. Barriers to uptake of pap smear test for cervical cancer screening in semi-urban district of Andhra Pradesh-one-year study. IOSR J Dent Med Sci. 2018;17(2):37-40.

13. Miller AB, Nazeer S, Fonn S, Brandup-Lukanow A, Rehman R, Cronje H, et al. Report on consensus conference on cervical cancer screening and management. Int J Cancer. 2000;86:440-7.

14. Jacquiline S, Cristina H, Christopher E. Cervical cancer in developing world. West $\mathbf{J}$ Med. 2001;175:231-3.

15. Senapathy JG, Umadevi P, Kannika PS. The present scenario of cervical cancer control and HPV epidemiology in India: an outline. Asian Pac J Cancer Prev. 2011;12:1107-15.

16. Adab P, McGhee SM, Yanova J, Wong CM, Hedley AJ. Effectiveness and efficiency of opportunistic cervical cancer screening: comparison with organized screening. Med Care. 2004;42:600-9.

17. Kulkarni PR, Rani H, Vimalambike MG, Ravishankar S. Opportunistic screening for cervical cancer in a tertiary hospital in Karnataka, India. Asian Pac J Cancer Prev. 2013;14(9):5101-5.

18. Nayar R, Wilbur DC. The Bethesda System for reporting cervical cytology: definitions, criteria, and explanatory notes. $3^{\text {rd }}$ ed. New York, Springer; 2015.

19. Saha D, Ghosh S, Nath S, Islam H. Utility of Pap smear screening for prevention of cervical cancer- A 3 yrs study from rural Tripura - a northeastern state of India. Int J Med Dent Sci. 2017;6(2):1456-61.

20. Verma A, Verma S, Vashist S, Attri S, Singhal A. A study on cervical cancer screening in symptomatic women using Pap smear in a tertiary care hospital in rural area of Himachal Pradesh, India. Mid East Fertil Soci J. 2017;22(1):39-42.

21. Shanmughum D, Vijay A, Rangaswamy $T$. Colposcopic evaluation of patient with persistent inflammatory pap smear. Sch J App Med Sci. 2014;2:1010-3.

22. Maleki A, Ahmadina E, Avazeh A, Mazloomzadeh S, Molaei B, Jalilvand A. Prevelance of abnormal papanicolaou test results and related factors among women living in Zanjan, Iran. Asian Pac J Cancer Prev. 2015;16:6935-9.

23. International Institute for Population Sciences (IIPS) and ICF. 2017. National Family Health Survey (NFHS-4), 2015-16: State Factsheet Bihar. Mumbai: IIPS. Available at: http://rchiips.org/NFHS/pdf/NFHS4/BR_FactSheet.p df. Accessed on $5^{\text {th }}$ May 2020.

24. Castellsagué $X$ and Muñoz N. Cofactors in human papillomavirus carcinogenesis-role of parity, oral 
contraceptives, and tobacco smoking. Journal of the National Cancer Institute. Monographs. 2003;3:20-8.

25. Desai M. An assessment of community-based cancer screening program among Indian Women Using the Anganwadi Workers. J Obstet Gynecol Ind. 2004:54:483-7.

26. Mishra P, Thapa R, Dinkar AK. A study on cervical cancer screening using pap smear in urban area in state of Meghalaya, India. Int J Reprod Contracept Obstet Gynecol. 2018;7:3113-6.

27. Omna S, Chakrabarty BK, Nagaraja N. A study on cervical cancer screening in asymptomatic women using Papanicolaou smear in a tertiary care hospital in an urban area of Mumbai, India. J Family Med Prim Care. 2018;7(4):652-7.

28. Sachan PL, Singh M, Patel ML, Sachan R. A study on cervical cancer screening using pap smear test and clinical correlation. Asia Pac J Oncol Nurs. 2018;5:337-41

29. Padmini CP, Indira N, Chaitra R, Das P, Girish BC, Nanda KM, et al. Cytological and colposcopic evaluation of unhealthy cervix. J Evid Med Healthc. 2015;2:6920-7.

Cite this article as: Sinha R, Kumar P, Singh G, Saha R. Opportunistic cervical cancer screening by papanicolaou stain Pap smear among women: a pilot study at urban health training centre of All India Institute of Medical Sciences, Patna, Bihar, India. Int J Reprod Contracept Obstet Gynecol 2020;9:271420. 